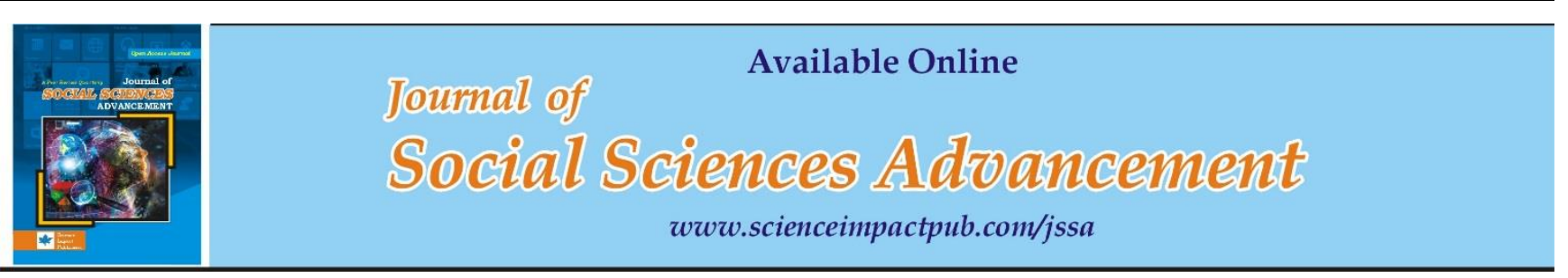

\title{
Flipped Classroom Instruction as a Teaching Tool for Meaningful Learning of the core Subjects in Junior High School: Basis for Instructional Development Plan
}

\author{
Renz Jervy A. Book ${ }^{1^{*}}$ \\ 1Zamboanga National High School West
}

\begin{abstract}
This study aimed to determine the effects of two teaching methods namely, flipped classroom instruction and conventional instruction in teaching the least mastered competencies in the core subjects among Grade 8 students in one of the Junior High Schools in Zamboanga City who were purposively selected. A Quasi-Experimental Research using the non-randomized pre-test - post-test control group design and qualitative approach explored the effectiveness of the two teaching methods. The findings indicated that students in flipped classroom instruction and conventional instruction obtained higher scores in the post-test than the pre-test results in the core subjects. But, flipped classroom students got slightly higher mean scores as compared to those students who have been taught in the conventional instruction. However, statistically, no significant difference was found between the two methods in learning the least mastered competencies in Science, Mathematics and English. Further, results revealed that the students who were exposed to flipped classroom instruction and the conventional instruction improved in their level of knowledge in mastering the least learned concepts in the core subjects. The problems encountered in the flipped classroom model, however, were identified based on the interview conducted. It was found out that teachers were unfamiliar with the flipped classroom model and lack of time and resources hindered them to utilize the approach in their classes. Students were also challenged particularly on the availability of resources like gadgets and internet connection that resulted to disengagement of the students to watch the flipped videos at home. This study revealed that whatever method or approach used in teaching least mastered competencies would be considered effective in achieving life-long and meaningful learning. An instructional development program was developed to capacitate and elevate the performance of teachers in the implementation of the flipped classroom instruction to improve students' performance.
\end{abstract}

\begin{tabular}{l}
\hline Keywords: Flipped Classroom Instruction; Conventional Instruction; Least Mastered Competencies \\
\hline${ }^{*}$ Corresponding Author: Renz Jervy A. Book, Email: renzjervy.book@deped.gov.ph \\
(C) The Author(s) 2021.
\end{tabular}

\section{INTRODUCTION}

It is a fact that teachers play varied and vital roles in the classroom. A teacher must be competent and knowledgeable to impart knowledge to their students. Effective teaching is when students feel safe and secure inside the classroom and be the positive influence in their lives. The teacher must recognize individual differences among students and adjust instructions that best suit the learners. When students are motivated, then learning will easily take place (Barberos, Gozalo, \& Padayogdog, 2012). A teacher must be equipped with variety of teaching approaches or styles to keep the learners motivated inside and outside the classroom.

However, motivating students to learn requires a very challenging role on the part of the teacher. It requires a variety of teaching styles or techniques just to capture students' interests.

When considering the approach to instruction, teachers always look for the method that is most beneficial to all learners. Teachers want their students to enjoy the learning process, and they want the classroom to be orderly and controlled. As a result, the debate of teacher-centered vs. student-centered education has been in the forefront of educators' minds for many years.

A study was conducted by teachers from United Kingdom to investigate how Chinese students performed well in class. It was found out the Chinese favors a "chalk and talk" approach, where teachers take greater control in class as compared to other countries like United States of America, Australia, United Kingdom, and others have moved away from this type of instruction to a more collaborative learning (Donelly, 2014).

A current trend in the education where teachers are flipping out their classroom. This trend is known as the "flipped classroom instruction". It is an inverted classroom where the lecture and homework have been switched or reversed. This is an approach where the direct instruction or lecture normally given during class time and is now given as a homework through reading course literature and assimilate lecture material through videos at home. While the 
practice problems normally completed as homework are now accomplished in the classroom through teacher-guided problem-solving, analysis and discussions in class.

However, there are many misconceptions that came out about the flipped classroom instruction. Accordingly, flipped classroom is an online class where students spend most of their time in front of their computers or gadgets such as iPad, laptop and smartphones. Students worked in isolation and without the guidance of the teacher. Lastly, videos can replace the teachers.

According to Tucker (2012), the most meaningful learning in a flipped classroom occurs because of efficient use of the extra class time. An effective flipped classroom model, is when the time normally spend for lecture discussion method is now being used to a more collaborative function during in-class activities to solve problems, perform group projects and many more. The direct instruction given to students as homework comes in different forms such as videos, an article, a book, a power point, a handout, or a combination of these among other. Any teacher who has led students to read materials before class to prompt discussion or activities, was able to utilize the flipped classroom instruction.

In addition, several proponents of flipped classroom listed numerous advantages of switching from traditional instruction to flipping their classroom. According to Gilboy, Heinerichs, and Pazzaglia (2015), flipped classroom model allows students to learn in their own pace, it encourages students to actively engage with lecture material, it frees up actual class time for more effective, creative, and active learning activities, teachers receive expanded opportunities to interact with and to assess students' learning, and students take control and responsibility for their learning.

With the implementation of the K to 12 Science Curriculum in the Philippines, there have been a lot of questions as to how students can cope with the demands of the content and performance standards imposed in every grade level. Apart from this, issues on the lack of learning modules and teacher's guide have also been the greatest concern of most teachers in the field.

Studies have shown that the teaching styles of teachers greatly affect students' academic performance (Tonog, 2015). Based on the observations of the department head and master teachers in one of the biggest schools in Zamboanga City, it was found out that there were teachers who were still engaging in a traditional method of teaching concepts despite of the series of trainings conducted by the Department of Education to meet the demands, interest, and abilities of the students in the $21^{\text {st }}$ Century. This resulted to a low academic performance of the students especially in the core subjects based on the computed Mean Percentage Score (MPS) in Grade 8 Curriculum. This situation was a cause for concern.

There is a need for more advanced approaches for teachers to become more effective and efficient in teaching concepts in core subjects where students could gain meaningful life-long learning. Considering one's teaching style and how it affected students' motivation greatly concerned the researcher. This reason led the researcher to the conception of this research study.

\section{Statement of the Problem}

This study aimed to determine the effects of two teaching methods namely, flipped classroom instruction and conventional instruction in teaching the least mastered competencies in the core subjects among Grade 8 students in one of the Junior High Schools in Zamboanga City.

Specifically, this study sought to answer the following questions:

i. What is the pre-test and post test results of the Grade 8 students in Science, Mathematics and English subjects using Flipped Classroom Instruction?

ii. What is the pre-test and post test results of the Grade 8 students in Science, Mathematics and English subjects using the Conventional Instruction?

iii. What are the issues and challenges encountered by the teachers and students on the implementation of the Flipped Classroom Instruction?

iv. Is there a significant difference in the post test results of the Grade 8 students in Science, Mathematics and English after using the Flipped Classroom Instruction and the Conventional Instruction?

v. On the basis of the findings, what instructional development program can be formulated?

\section{METHODOLOGY}

This study employed mixed-method of data collection. Quasi-Experimental Research and employed the NonRandomized Pre-test-Post-test Control Group Design. In this design, two groups were used, with both groups measured or observed twice. The measurement of observation of both groups was collected and subjected to statistical treatment. Meanwhile, Qualitative Design was used in gathering data that can merit the descriptions of the 
issues and challenges that the teachers and students encountered in the implementation of the Flipped Classroom Instruction.

This study was conducted in one of the biggest schools in Zamboanga City. It is a school in the west that stands proudly along by the sea and situated at 9,750 sq. meters piece of land along R.T. Lim Boulevard right next to the Joaquin F. Enriquez Jr. Memorial Sports Complex. The respondents of the study were Grade 8 students enrolled under Science, Technology, Engineering and Mathematics Program (STEM) during the school year 2019 - 2020. The selection of the samples was done using purposive sampling. Two (2) sections of the Grade 8 STEM A and B consisting of 31 students each were used as the respondents of this study. The experimental group was taught the least mastered competencies in Science, Mathematics and English through Flipped Classroom Instruction while the control group was taught the same content through Conventional Instruction. The tossing of coins was conducted to identify which class would be the experimental and which class would be the control group.

In this study the researcher used two (2) research instruments: First, was the teacher-made Pre-Post Test on the least mastered competencies in Science, Mathematics and English. And second, was the interview questionnaires both for teachers and students. The mean, standard deviation, paired sample t-test and independent sample t-test were the primary statistical tools used in the analysis of data.

\section{RESULTS AND DISCUSSIONS}

The first research question that this study sought to answer was, "What is the pre-test and post- test score of the Grade 8 students in Science, Mathematics, and English subjects using the Flipped Classroom Instruction?

Table 1: Scores of the Grade 8 students in Science, Mathematics, and English Subjects using the Flipped Classroom Instruction

\begin{tabular}{cccccc}
\hline \multirow{2}{*}{ Subject } & \multicolumn{2}{c}{ Pretest } & \multicolumn{2}{c}{ Post test } & \multirow{2}{*}{ Remarks } \\
\cline { 2 - 5 } & Mean & SD & Mean & SD & \\
\hline Science & 10.87 & 2.62 & 20.52 & 3.98 & Increase \\
Mathematics & 8.61 & 2.03 & 20.26 & 3.97 & Increase \\
English & 16.06 & 4.39 & 24.39 & 2.33 & Increase \\
\hline
\end{tabular}

Table 1 shows the Pre-test and Post test scores of the Grade 8 students in Science, Mathematics and English using the Flipped Classroom Instruction. The pre-test showed a mean of 10.87 with a standard deviation of 2.62 in Science, 8.61 with a standard deviation of 2.03 in Math and 16.06 with a standard deviation of 4.39 in English. The post test results showed that Flipped Classroom group got an improved mean score of 20.52 with a standard deviation of 3.98 in Science, 20.26 with a standard deviation of 3.97 in Math and 24.39 with a standard deviation of 2.33 in English.

A comparison of the pre-test and post-test results showed that the post-test results of the Flipped Classroom group to be higher than the pre-test results. This means that student's score was increased after having been given lessons particularly the least mastered competencies in Science, Mathematics and English using the Flipped Classroom Instruction.

This result is supported by the constructivist theorist's positions with regards to knowledge acquisition. According to Kapur (2019), when learners are engaged in constructing their own viewpoints, they carry their life experiences to fully grasp the concepts provided and be able to put it in action. This is where the teacher comes in as facilitator but not as a dispenser of knowledge. Learners still need to acknowledge ideas and suggestions from their teachers to make sure that they are properly guided and on the right track. It emphasizes the importance of the learner being actively involved in the learning process. Thus, the used of the Flipped Classroom Instruction as a student-centered approach in learning the least mastered competencies in Science, Mathematics and English developed students' new insights, encouraged them to work independently, explore new opportunities, make their own interpretation, and generate their own conclusions. This was very evident during the out-of-class and interaction with the teacher inside the classroom which resulted to an increase in the pre-test to post test score of the students who were exposed to the flipped classroom instruction.

The second research question that this study sought to answer was, "What is the pre-test and post-test score of the Grade 8 students in Science, Mathematics, and English subjects using the Conventional Instruction?"

Table 2: Scores of the Grade 8 students in Science, Mathematics, and English Subjects using the Conventional Instruction

\begin{tabular}{cccccc}
\hline \multirow{2}{*}{ Subject } & \multicolumn{2}{c}{ Pre-test } & \multicolumn{2}{c}{ Post test } & \multirow{2}{*}{ Remarks } \\
\cline { 2 - 5 } & Mean & SD & Mean & SD & \\
\hline Science & 10.26 & 1.81 & 19.52 & 3.87 & Increase \\
Mathematics & 9.42 & 2.74 & 19.32 & 3.41 & Increase \\
English & 16.71 & 3.92 & 23.94 & 3.03 & Increase \\
\hline
\end{tabular}

Table 2 shows the Pre-test and Post-test scores of the Grade 8 students in Science, Mathematics and English using the Conventional Instruction. The pre-test showed a mean of 10.26 with a standard deviation of 1.81 in Science, 9.42 with 
a standard deviation of 2.72 in Math and 16.71 with a standard deviation of 3.92 in English. The post test results showed that Conventional Instruction group got an improved mean score of 19.52 with a standard deviation of 3.87 in Science, 19.32 with a standard deviation of 3.41 in Math and 23.94 with a standard deviation of 3.03 in English.

A comparison of the pre-test and post-test results showed that the post-test results of the Conventional Instruction group to be higher than the pre-test results. This means that student's score was increased after having been given lessons particularly the least mastered competencies in Science, Mathematics and English using the Conventional Instruction.

This result is supported by the behaviorist theorist's positions with regards to knowledge acquisition. Behaviorist relies on the active role of the teacher as the dispenser of knowledge and skills. Teacher uses direct instruction through lecture discussion method to ensure that learning takes place (Bandura, 1986). The traditional method of teaching as a teacher-centered approach was greatly observed during the entire duration of the experimentation. The teacher relied heavily on drill and practice in order for the students to learn the concepts presented and has proven to be effective as the scores of the students who were exposed to the conventional instruction improved from the pretest to post test in Science, Mathematics and English. According to Donges (2017), this type of approach will not allow the students to perform higher thinking skills such as to solve problems, apply to new situations and evaluate their experiences as this theory disregards collaboration and communication.

The third research question that this study sought to answer was, "What are the issues and challenges encountered by the teachers and students during the implementation of the Flipped Classroom Instruction?"

\section{SUMMARY OF INTERVIEW FINDINGS}

The one-on-one interview conducted to the teachers and student- respondents determined the qualitative description of the issues and challenges of the teachers and students in the implementation of the Flipped Classroom Instruction.

\section{It Takes Time}

According to the teachers, in the preparation of the lesson using the flipped classroom instruction usually takes $2-3$ hours per day. In this case, teachers need to spend more time in the preparation specifically in choosing the correct video clip that is suitable and relatable for the students. The flipped learning videos must contain several elements such as animation, cartoon, and music to attract students' attention to watch it. If not, students will most likely not to engage in watching the videos at home. Teachers need also extra time in preparation of the instructional materials to be used in the execution of the flipped instruction such as the multi-media tools. Lastly, the planning of the lesson must be prepared ahead of time. Teachers devoted their time to come up with a well-polished lesson plan to meet the interest of the students depending on their learning styles. Choosing the best learning strategy to fit student's learning style takes most of the time of the teachers. As they need to search for the best activity that meets the learning style of the students in the classroom.

\section{Unfamiliarity of the Approach}

Teachers are not familiar with the approach and never made used as a learning strategy in class. This becomes a challenge to the teachers as most of them are not train to this type of approach. Teachers are not able really to monitor the progress of the students especially in watching the videos during out-class. Teachers may not be aware that some students were not able to view the flipped learning videos at home because students don't have the access for internet connection. Students struggled but with the help of their classmates or peers they were able to find ways to watch the lesson and be ready for the in-class activities. The teacher must then be a master of this approach as he or she plays a vital role in the outcome of this approach. The in-class activities are important for students' hands-on activities, group discussion, or inquiry-based learning to construct their critical and creative thinking. However, teachers are still new to this type of approach which can influence students' successful learning of the least mastered competencies in Science, Mathematics and English.

\section{Lack of Resources}

On the part of the students, several problems were also encountered during the implementation of the Flipped Classroom Instruction. The theme that emerged is the lack of resources. The students used the Schoology Application as platform for out-class instruction. Students were asked to view the video, read the power point and other materials uploaded in the application. Students were instructed to view the videos at their most convenient time at home which served as advance lesson for them to be ready for the next day. It was expected that most of the students were able to view the videos at home. Unfortunately, some of students experienced some difficulties in accessing the videos using the application due to limited resources such as no internet connection at home, no gadgets available and the likes which resulted to disengagement of the students to watch the video at home. Aside from that, students have 
mentioned that because of heavy-loaded requirements from other subjects, they did not have time to access the flipping videos at home. This could affect the performance of the students during in-class interaction.

The fourth research question that this study sought to answer was, "Is there a significant difference between the posttest scores of the Grade 8 Students in Science, Mathematics and English after using Flipped Classroom Instruction and Conventional Instruction?

Table 3: Significant Difference in the Post test Results of the Grade 8 students in Science, Mathematics, and English Subjects using the Flipped Classroom and Conventional Instruction

\begin{tabular}{|c|c|c|c|c|c|c|}
\hline Subject & Group & Mean Post test Scores & t-value & P-value & Remarks & Decision on Ho \\
\hline Science & $\begin{array}{l}\text { Flipped Classroom Instruction } \\
\text { Conventional Instruction }\end{array}$ & $\begin{array}{l}20.52 \\
19.52\end{array}$ & 1.002 & 0.320 & Not significant & Accept Ho \\
\hline Mathematics & $\begin{array}{c}\text { Flipped Classroom Instruction } \\
\text { Conventional Instruction }\end{array}$ & $\begin{array}{l}20.26 \\
19.32\end{array}$ & 0.995 & 0.324 & Not significant & Accept Ho \\
\hline English & $\begin{array}{l}\text { Flipped Classroom Instruction } \\
\text { Conventional Instruction }\end{array}$ & $\begin{array}{l}24.39 \\
23.94\end{array}$ & 0.657 & 0.514 & Not significant & Accept Ho \\
\hline
\end{tabular}

Table 3 shows the significant difference in the post-test scores of the Grade 8 students in Science, Mathematics and English using the Flipped Classroom Instruction and Conventional Instruction. As it can be gleaned from the table above, post-test scores in Science for Flipped Classroom group obtained slightly higher mean of 20.52 as compared to the Convention Instruction group with a mean score of 19.52. Independent samples T-test was used when data were compared. As seen in the table, the yielded $t$-value for Science is 1.002 with a P-value of 0.320 . Since the Pvalue is greater than 0.05 level of significance this means the difference is statistically not significant. This can be inferred that the flipped classroom instruction and conventional instruction used in this study were believed to be both effective as an instructional method in teaching the least mastered competencies in Science.

In like manner, post-test scores in Mathematics for Flipped Classroom group obtained slightly higher mean of 20.26 as compared to the Conventional Instruction group with a mean of 19.32. Independent samples T-test was used when data were compared. As seen in the table, the yielded t-value for Mathematics is 0.995 with a P-value of 0.324 . Since the P-value is greater than 0.05 level of significance this means the difference is statistically not significant. This can be inferred that the flipped classroom instruction and conventional instruction used in this study were believed to be both effective as an instructional method in teaching the least mastered competencies in Mathematics.

Moreover, post-test scores in English for Flipped Classroom group obtained slightly higher mean of 24.39 as compared to the Conventional Instruction group with a mean of 23.94. Independent samples T-test was used when data were compared. As seen in the table, the yielded t-value for Mathematics is 0.657 with a P-value of 0.514 . Since the P-value is greater than 0.05 level of significance this means the difference is statistically not significant. This can be inferred that the flipped classroom instruction and conventional instruction used in this study were believed to be both effective as an instructional method in teaching the least mastered competencies in English.

These findings can be supported by the conclusion of Hackatorn, et al. (2011) that each teaching technique has its own benefits and effectiveness for various levels of learning and emphasizes that active teaching techniques aid in increasing learning. Using the two (2) approaches in teaching the least mastered competencies in the core subjects improved the level of performance of the Grade 8 students.

This result can also be supported by an investigation conducted by Cabi (2018) on the impact of the Flipped Classroom (FC) Model on students' academic achievement. Students under experimental group were exposed to flipped classroom instruction while the control group were carried out through traditional blended learning in a span of four (4) weeks. Based on the results, it was found out that were no statistically significant differences between the scores of the two groups. It was identified that one of the positive aspects of the flipped classroom model is that students are coming to class prepared and able to complete the assignments in class not at home. On the other hand, problems encountered in this model were categorized as Motivation, Content, and Learning.

This finding can also be supported by a study conducted by Love, Hodge, Grandgenett and Swift (2013) to STEM classes of an applied linear algebra course, using the traditional lecture and the flipped classroom model. Based on the results, students in the flipped classroom environment had a more significant increase between the sequential exams compared to the students in the traditional lecture section, while performing similarly in the final exam. Also, the flipped classroom students were very positive about their experience in the course, and particularly appreciated the student collaboration and instructional video components.

This result can be supported by a study conducted by Stratton, et al. (2020) on comparing face-to-face instruction and flipped learning on the Grade 7 students' achievement in Science classes. The results revealed that there is no difference in performance between the two groups of students. It was reported that students increased engagement 
and motivation due to the fact that majority of the students enjoyed the flipped model. This study concluded that flipped instruction was as effective as face-to-face instruction.

Table 4: Significant Difference in the Pre-test and Post-test Results of the Grade 8 students in Science, Mathematics, and English Subjects using the Flipped Classroom Instruction

\begin{tabular}{|c|c|c|c|c|c|c|}
\hline Subject & Group & Mean Scores & t-value & $\mathrm{P}$-value & Remarks & Decision on Ho \\
\hline Science & $\begin{array}{l}\text { Pre test } \\
\text { Post test }\end{array}$ & $\begin{array}{l}10.87 \\
20.52 \\
\end{array}$ & -11.088 & 0.000 & Significant & Reject Ho \\
\hline Mathematics & $\begin{array}{l}\text { Pre test } \\
\text { Post test }\end{array}$ & $\begin{array}{c}8.67 \\
19.81 \\
\end{array}$ & -12.091 & 0.000 & Significant & Reject Ho \\
\hline English & $\begin{array}{l}\text { Pre test } \\
\text { Post test }\end{array}$ & $\begin{array}{l}16.00 \\
24.19\end{array}$ & -8.817 & 0.000 & Significant & Reject Ho \\
\hline
\end{tabular}

Table 4 shows the significant difference in the pre-test and post-test scores of the Grade 8 students using the Flipped Classroom Instruction. T-test was used when data were compared. As seen in the table, the yielded t-value for Science is -11.088 with a P-value of 0.000 . Since the P-value is less than 0.05 level of significance this means the difference is statistically significant. This can be inferred that the Flipped Classroom Instruction yields better performance from pre-test to post-test in learning the least mastered competencies in Science.

In like manner, the yielded t-value for Mathematics is -12.091 with a P-value of 0.000 . Since the P-value is less than 0.05 level of significance this means the difference is statistically significant. This can be inferred that the Flipped Classroom Instruction yields better performance from pre-test to post-test in earning the least mastered competencies in Mathematics.

Moreover, the yielded t-value for English is -8.817 with a P-value of 0.000 . Since the P-value is less than 0.05 level of significance this means the difference is statistically significant. This can be inferred that the Flipped Classroom Instruction yields better performance from pre-test to post-test in learning the least mastered competencies in English.

The result implies that Flipped Classroom Instruction is an effective approach in teaching the least mastered competencies in Science, Mathematics and English. The students' score significantly increased from Pre-Test to Post Test. This is because of the active input of the students in the teaching-learning process. This claimed can be supported by a constructivist learning model that requires intellectual effort and aids retention.

Social constructivism emphasized the importance of learners being actively involved in the learning process that they construct their own understanding and do not simply mirror or reflect what they read. On the other hand, teachers' role in the student-centered learning is to facilitate the students' learning by providing a framework that facilitates their learning. In this study, flipped learning inverted the traditional approach, where students completed work at home by watching flipped videos for collaborative activities to happen during in-class.

Table 5: Significant Difference in the Pre-test and Post-test Results of the Grade 8 students in Science, Mathematics, and English Subjects using the Conventional Instruction

\begin{tabular}{ccccccc}
\hline Subject & Group & Mean Scores & t-value & P-value & Remarks & Decision on Ho \\
\hline \multirow{2}{*}{ Science } & $\begin{array}{c}\text { Pre test } \\
\text { Post test }\end{array}$ & $\begin{array}{c}10.23 \\
19.06\end{array}$ & -10.967 & 0.000 & \multirow{2}{*}{ Significant } & \multirow{2}{*}{ Reject Ho } \\
\hline \multirow{2}{*}{ Mathematics } & $\begin{array}{c}\text { Pre test } \\
\text { Post test }\end{array}$ & $\begin{array}{c}9.40 \\
18.94\end{array}$ & -11.225 & 0.000 & \multirow{2}{*}{ Significant } & \multirow{2}{*}{ Reject Ho } \\
\hline \multirow{2}{*}{ English } & $\begin{array}{c}\text { Pre test } \\
\text { Post test }\end{array}$ & $\begin{array}{c}16.57 \\
23.84\end{array}$ & -8.097 & 0.000 & \multirow{2}{*}{ Significant } & \multirow{2}{*}{ Reject Ho } \\
\hline
\end{tabular}

Table 5 shows the significant difference in the pre-test and post-test scores of the Grade 8 students using the conventional classroom instruction. T-test was used when data were compared. As seen in the table, the yielded tvalue for science is -10.967 with a P-value of 0.000 . Since the P-value is less than 0.05 level of significance this means the difference is statistically significant. This can be inferred that the Conventional Instruction yields better performance from pre-test to post-test in learning the least mastered competencies in Science.

In like manner, the yielded t-value for Mathematics is -11.225 with a P-value of 0.000 . Since the P-value is less than 0.05 level of significance this means the difference is statistically significant. This can be inferred that the Conventional Instruction yields better performance from pre-test to post-test in learning the least mastered competencies in Mathematics.

Moreover, the yielded t-value for English is -8.097 with a P-value of 0.000 . Since the P-value is less than 0.05 level of significance this means the difference is statistically significant. This can be inferred that the Conventional Instruction yields better performance from pre-test to post-test in learning the least mastered competencies in English. 
The result implies that Conventional Instruction is also an effective approach in teaching the least mastered competencies in Science, Mathematics and English. The students' score significantly increased from Pre-Test to Post Test. This can be supported by the behaviourist theorist positions with regards to knowledge acquisition. Behaviourist relies on the active role of the teacher as the dispenser of knowledge and skills in a teacher-centered approach. As Banduara stated, teacher used direct instruction through lecture-discussion method to ensure that learning takes place and has proven effective which relies mostly in drills and practices.

\section{CONCLUSIONS}

After careful analysis of data, this study, therefore, presents the following conclusions:

1. Post-test result is higher than the pre-test result of the Flipped Classroom group.

2. Post-test result is higher than the pre-test result of the Conventional Instruction group.

3. The issues encountered by the teachers in the implementation of the Flipped Classroom Instruction were the following: the time spent in the preparation of the materials in the execution of the approach takes time while challenges encountered are the unfamiliarity of the approach and the lack of resources. On the other hand, students enumerated problems encountered in the implementation of the Flipped Classroom. These are the following: poor internet connection leads students to disengagement in the out-of-class; not all students have the access on the internet connection at home; and the lack of resources such as smartphones and laptops.

4. There is no significant difference in post-test scores of the Grade 8 Students of the Flipped Classroom Instruction and the Conventional Instruction in learning the least mastered competencies in Science, Mathematics and English.

\section{RECOMMENDATIONS}

In view of the conclusions, this study makes the following recommendations;

The principal must be able to design a plan and an educational development program focusing on the implementation of the flipped classroom instruction. This study will pave way for the school principal to encourage teachers to adopt this effective teaching tool for classroom instruction. There must be a continuous training so that teachers will develop the skills and master the proper execution of the flipped classroom instruction.

The head together with the Master Teacher of the department must plan series of training for teachers on the proper implementation of the flipped classroom. They can insert the training during In-Service Training every October and May. The training must focus on developing the teachers $21^{\text {st }}$ Century Skills which is needed in the execution of the flipped classroom instruction.

The teacher must continue to ignite their interests and eagerness in teaching. Teachers should be more innovative in preparing teaching and learning materials to help them modify their teaching strategies in order to embrace the benefits of interactive teaching, including longer and increased students' conceptual understanding. Teachers can adopt the teaching method introduced in this study to embark on effective teaching techniques on the different lessons, thus enhancing the pedagogical practice of the teachers.

The learners under the STEM Program should be able to develop good attitude and positive prerogative towards the subject. Through this, it can increase students' academic performance in exposing them to the appropriate teaching techniques that can assist them to gain meaningful and lifelong learning. Students must be able to understand why teachers used flipped classroom instruction. Students can also develop and enhance their $21^{\text {st }}$ Century skills.

A Cohort study be conducted from Grade 7 to Grade 10 applying the same methodology used in this study to make the study more conclusive and comprehensive; similar research be conducted in other subject areas such as MAPEH and Araling Panlipunan; and a replication of this research be conducted using the whole semester or one school year for experimentation to assess the long-term effects of the teaching methods used.

\section{REFERENCES}

Bandura, A. (1986). Social foundations of thought and action: A social cognitive theory. Englewood Cliffs, NJ: PrenticeHall.

Barberos, M. T., Gozalo, A. \& Padayogdog, E. (2012). The Effects of the Teaching Style on Students' Motivation Action Research, Retrieved January 3, 2018 from https: steinhardt-nyu.edu/teachlearn/research/action/motivation 
Cabi, E. (2018). The impact of the flipped classroom model on students' academic achievement. International Review of Research in Open and Distributed Learning, 19(3). https://doi.org/10.19173/irrodl.v19i3.3482

Donelly, K. (2014). Chalk and Talk' teaching might be the best way after all. Retrieved January 3, 2018 from http://theconversation.com/chalk-and-talk-teaching-might-be-the-best-way-after-all-34478

Donges, C. (2017). Theoretical Perspective on Behaviorism and What an Effective Teacher Understands. Retrieved on December 27, 2017 from https://classroom.synonym.com/theoretical-perspective-behaviorism-effectiveteacher-understands-20230.html

Gilboy, M. B., Heinerichs, S., \& Pazzaglia, G. (2015). Enhancing student engagement using the flipped classroom. Journal of nutrition education and behavior, 47(1), 109-114.

Hackathorn, J., Solomon, E. D., Blankmeyer, K. L., Terial R. E., and Garcynski, A. M. (2011). Learning by Doing, An Empirical Study of Active Teaching Techniques. The Journal of Effective Teaching

Kapur, R. (2019). Constructivism in Teaching-Learning Process. University of Delhi Retrieved September 18, 2020 from https://www.researchgate.net/publication/333507499_Constructivism_in_Teaching-Learning_Process

Love, B., Hodge, A., Grandgenett, N. \& Swift, A. (2014) Student learning and perceptions in a flipped linear algebra course, International Journal of Mathematical Education in Science and Technology, 45:3, 317324, DOI: 10.1080/0020739X.2013.822582

Stratton, E. , Chitiyo, G. , Mathende, A. M. \& Davis, K. M. (2020). Evaluating Flipped Versus Face-to-face Classrooms in Middle School on Science Achievement and Student Perceptions . Contemporary Educational Technology , 11 (1) , 131-142 . DOI: 10.30935/cet.646888

Tonog, M. N. (2015). The effect of teaching and learning styles on students' academic achievement in general chemistry 1 at the University of eastern Philippines. Retrieved 20, 2018 from http://www.ijramr.com/issue/effect-teaching-and-learning-styles-students\%E2\%80\%99-academicachievement-general-chemist

Tucker, B. (2012) The Flipped Classroom. Education Next, 12

Publisher's note: Science Impact Publishers remain neutral with regard to jurisdictional claims in published maps and institutional affiliations.

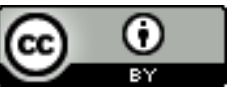

Open Access This article is licensed under a Creative Commons Attribution 4.0 International License, which permits use, sharing, adaptation, distribution and reproduction in any medium or format, as long as you give appropriate credit to the original author(s) and the source, provide a link to the Creative Commons license and indicate if changes were made. The images or other third-party material in this article are included in the article's Creative Commons license, unless indicated otherwise in a credit line to the material. If material is not included in the article's Creative Commons license and your intended use is not permitted by statutory regulation or exceeds the permitted use, you will need to obtain permission directly from the copyright holder. To view a copy of this license, visit https://creativecommons.org/licenses/by/4.0/.

(C) The Author(s) 2021 